\title{
The main controlling factors and developmental models of Oligocene source rocks in the Qiongdongnan Basin, northern South China Sea
}

\author{
Li Wenhao", Zhang Zhihuan', Li Youchuan' ${ }^{2}$, Liu Chao ${ }^{3}$ and Fu Ning ${ }^{2}$ \\ ${ }^{1}$ State Key Laboratory of Petroleum Resources and Prospecting, China University of Petroleum, Beijing 102249, China \\ ${ }^{2}$ CNOOC Research Institute, Beijing 100027, China \\ ${ }^{3}$ Petroleum Engineering College, China University of Petroleum, Beijing 102249, China
}

(C) China University of Petroleum (Beijing) and Springer-Verlag Berlin Heidelberg 2013

\begin{abstract}
Coals developed in the Oligocene Yacheng and Lingshui formations in the Qiongdongnan Basin have high organic matter abundance, and the dark mudstones in the two formations have reached a good source rock standard but with strong heterogeneity. Through the analysis of trace elements, organic macerals and biomarkers, it is indicated that plankton has made little contribution to Oligocene source rocks compared with the terrestrial higher plants. The organic matter preservation depends on hydrodynamics and the redox environment, and the former is the major factor in the study area. During the sedimentary period of the Yacheng Formation, tidal flats were developed in the central uplift zone, where the hydrodynamic conditions were weak and the input of terrestrial organic matter was abundant. So the Yacheng Salient of the central uplift zone is the most favorable area for the development of source rocks, followed by the central depression zone. During the sedimentary period of the Lingshui Formation, the organic matter input was sufficient in the central depression zone due to multiple sources of sediments. The semi-enclosed environment was favorable for organic matter accumulation, so high quality source rocks could be easily formed in this area, followed by the Yacheng salient of central uplift zone. Source rocks were less developed in the northern depression zone owing to poor preservation conditions.
\end{abstract}

Key words: Hydrocarbon generation potential, paleoproductivity, preservation conditions, hydrodynamic conditions, redox conditions, Oligocene source rocks, Qiongdongnan Basin, northern South China Sea

\section{Introduction}

The formation of excellent marine source rocks depends on the living environment of the original source organisms and favorable preservation conditions for organic matter, and these factors are controlled by a good matching relationship of paleoproductivity, hydrodynamic and redox conditions, paleoclimate and sedimentation rate (Zhang et al, 2005; Chen et al, 2006). Among these factors, paleoproductivity and preservation conditions (including hydrodynamic and redox conditions) are much more important. Since the 1980s, there has been debate on whether the high organic matter abundance in marine sedimentary strata is dependent on preservation conditions or on production. Those who hold the former view believe that organic matter accumulates when the bottom water conditions are anoxic, and it has nothing to do with biologic productivity (Tyson, 1987; Tyson and Pearson, 1991). While others consider that organic matter

*Corresponding author. email: zhangzh3996@vip.163.com Received July 24, 2012 can accumulate at the water column with high biologic productivity, and it is the water depth rather than the dissolved oxygen that influences the abundance of organic matter (Calvert and Pedersen, 1992). However, in continental margin basins, the terrestrial organic matter input is also a significant factor influencing the formation of marine source rocks. For example, rift basins along the Atlantic Ocean where excellent marine source rocks formed were mainly located below the estuary of big rivers, and the big rivers and delta offered a good material base for the development of source rocks (Zhou et al, 2007; Li et al, 2012; Deng, 2012).

The present crude oil and gas in the Qiongdongnan Basin are mainly from transitional facies source rocks of the Oligocene Yacheng Formation (Dong and Huang, 2000; Huang et al, 2002; Chen et al, 2005; Xiao et al, 2006; Zhu et al, 2009; Li et al, 2011; Huang et al, 2012). Marine source rocks developed in the Lingshui Formation can also serve as gas source rocks and may have certain oil generation potential ( $\mathrm{Li}$ et al, 2011). However, heterogeneity of source rocks is common in the study area, and the controlling factors are complex. There is still no relevant research on the controlling factors of Oligocene source rocks, which severely restricts 
the understanding of their hydrocarbon generation potential. Here we discuss the formation environment of source rocks in the Oligocene Yacheng and Lingshui formations through the analysis of paleoproductivity, terrestrial organic matter input, hydrodynamic and redox conditions, thus revealing the main controlling factors of source rocks in the research area. We will eventually propose the developmental models of source rocks from the Yacheng and Lingshui formations in the Qiongdongnan Basin in order to provide an improved geological and geochemical basis for oil and gas exploration of northern South China Sea.

\section{Geological background}

The Qiongdongnan Basin stretching northeastward lies in the northwest continental margin of the South China Sea, which is located between Hainan Island and Xisha Islands. The basin is limited by four faults (Nos. 1, 5, 11, 12) and the area is about $3 \times 10^{4} \mathrm{~km}^{2}$. The western part of the basin is adjacent to the Yinggehai Basin, the northern part borders the Hainan Uplift, the southeastern part is adjacent to the XishaZhongsha uplifts and the eastern part is adjacent to the Zhu II Depression in the Pearl River Mouth Basin (Fig. 1) (Hu, 2005). The basin evolution and fill share many similarities with passive continental margin basins (Gong et al, 2011), characterized by a typical double-layer structure. The lower structural layer formed in rifting period consists of Eocene, and Yacheng and Lingshui formations in Oligocene. During this period, the sedimentary facies changed from lacustrine to transitional facies characterized by coal-bearing deposition and marine deposits. In addition, multiple sags and uplifts developed in the lower structure layer. The upper structural layer formed in the post-rifting period is characterized by marine Neogene and Quaternary strata. The upper structural layer has weak deformation and small fault activities. The base of the Qiongdongnan Basin consists of igneous, metamorphic and sedimentary rocks of Tertiary. The filling sequences of the basin are mainly Tertiary and Quaternary, which can be divided into the Eocene, Oligocene Yacheng and Lingshui formations, Miocene Sanya, Meishan and Huangliu formations, Pliocene Yinggehai Formation, and Quaternary from bottom to top (Fig. 2). Three sets of source rocks were developed in different sedimentary environments, and they are Eocene lacustrine mudstones (although there are no drilling wells, the seismic profile reveals the lacustrine deposition), Oligocene marine source rocks (including transitional facies source rocks in the Yacheng Formation and marine source rocks in the Lingshui Formation) and Miocene marine source rocks.

\section{Analytical samples and methods}

Source rock samples from the Yacheng and Lingshui formations were provided by CNOOC. $200 \mathrm{~g}$ samples were

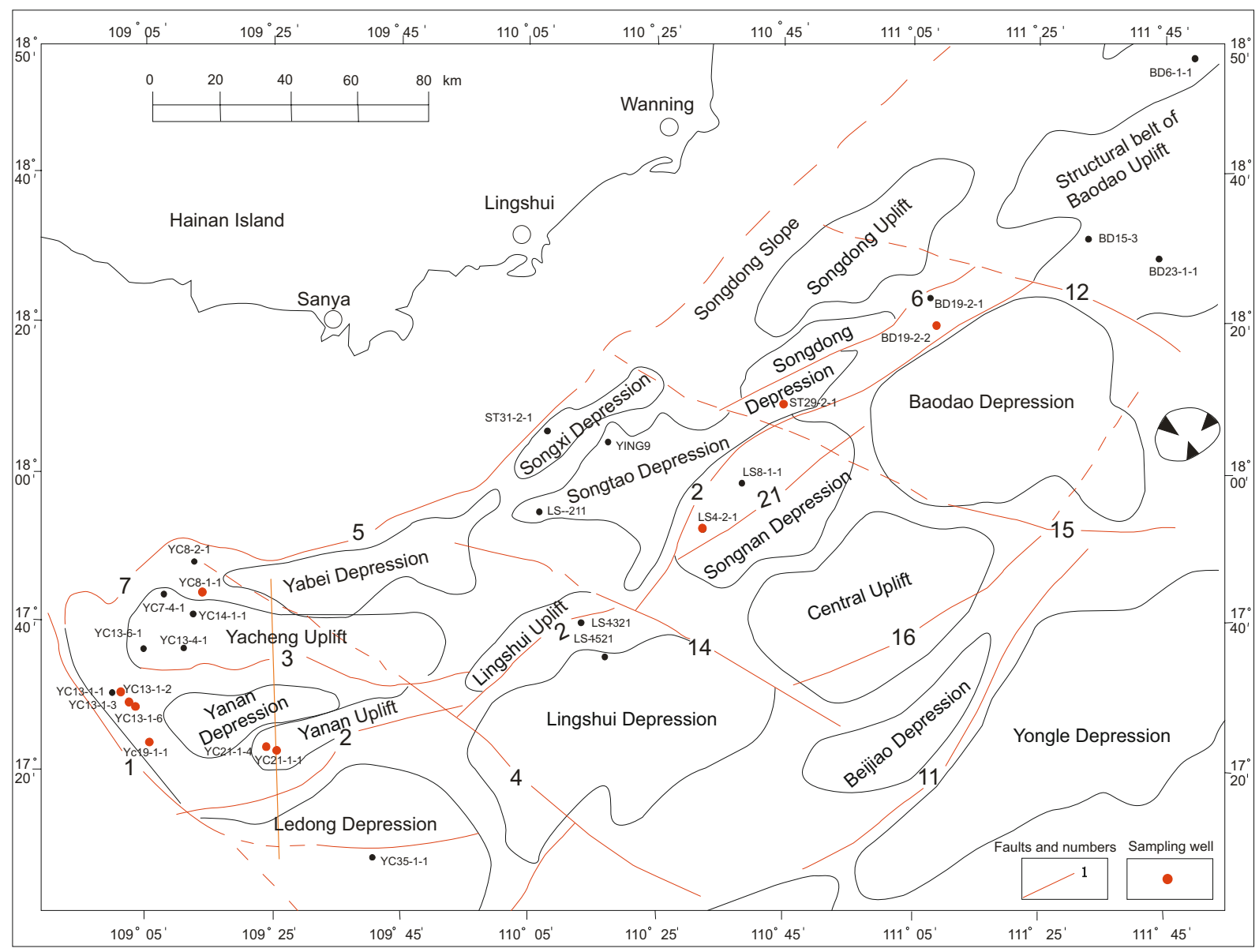

Fig. 1 The structural location of the Qiongdongnan Basin (Hu, 2005) 


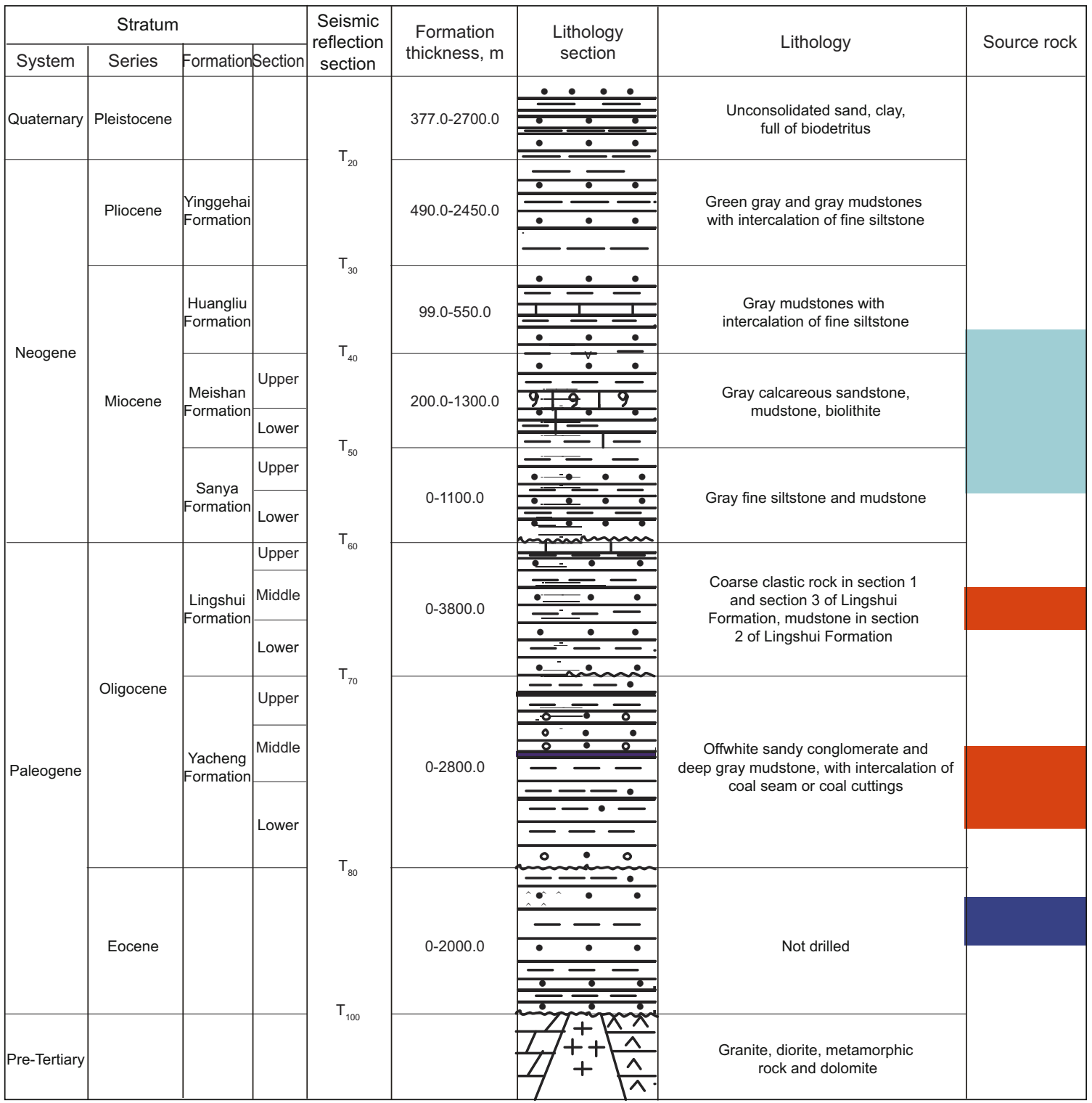

Fig. 2 Comprehensive stratigraphic column of the Qiongdongnan Basin

weighed and crushed to 80 mesh for total organic carbon and pyrolysis analysis, some of the samples were used for maceral analysis. The samples with TOC (total organic carbon) $>1 \%$ were chosen for extraction, and then were separated by chromatographic columns. The extracts were evaporated, deasphaltened with $n$-hexane, and then separated through column chromatography using silica gel and alumina $(3: 1)$ into the saturated, aromatic and polar fractions by $n$-hexane, dischloromethane and $n$-hexane $(2: 1, \mathrm{v}: \mathrm{v})$, and chloroform and ethanol $(1: 1, \mathrm{v}: \mathrm{v})$ as elution solvents, respectively. The saturated and aromatic fractions were analyzed by gas chromatography-mass spectrometry (GC-MS). The GC-MS analyses were performed on a Thermo-Finnigan Trace-DSQ equipped with an HP-5MS $(60 \mathrm{~m} \times 0.25 \mathrm{~mm} \times 0.25 \mu \mathrm{m})$ fused silica capillary column, operating in full scan modes. The GC-MS conditions were split injection at $300^{\circ} \mathrm{C}$, helium $(99.999 \%$ purity) as carrier gas, and oven temperature initially at $50{ }^{\circ} \mathrm{C}$ for $1 \mathrm{~min}$, programmed at $20^{\circ} \mathrm{C} / \mathrm{min}$ to $120^{\circ} \mathrm{C}$, then at $3{ }^{\circ} \mathrm{C} / \mathrm{min}$ to $310{ }^{\circ} \mathrm{C}$ and held at this temperature for 25 min. The mass spectrometer was operated in the EI (electron impact) mode at $70 \mathrm{eV}$ with a total scan range.

\section{Hydrocarbon generation potential analysis of Oligocene source rocks in the Qiongdongnan Basin}

The average values of TOC of coals and carbonaceous mudstones in the Yacheng Formation are respectively 53\% and $8 \%$, and the average values of RockEval pyrolysis data $\left(\mathrm{S}_{1}+\mathrm{S}_{2}\right)$ are $94 \mathrm{mg} / \mathrm{g}$ and $16 \mathrm{mg} / \mathrm{g}$ respectively (Table 1 ), which indicates high hydrocarbon generation potential. Mudstones in the Yacheng Formation also have favorable hydrocarbon generation potential with an average TOC value and $\left(\mathrm{S}_{1}+\mathrm{S}_{2}\right)$ of $1.0 \%$ and $0.8 \mathrm{mg} / \mathrm{g}$ respectively. In the Lingshui Formation, coals have high hydrocarbon generation potential and the marine source rocks also have reached a 
good source rock standard. The organic matter types of the source rocks in the Yacheng and Lingshui formations are mainly $\mathrm{II}_{2}$-III with high pyrolysis peak temperature $(>430$ ${ }^{\circ} \mathrm{C}$ ) and low hydrogen index (HI). The transitional facies source rocks in the Yacheng Formation (including coal and mudstone) are the major source rocks in the Qiongdongnan
Basin due to the high hydrocarbon generation potential. The neritic mudstones in the Lingshui Formation are slightly worse than the mudstones in the Yacheng Formation, but still reach a good source rock standard, which can serve as an important secondary source rock in the Qiongdongnan Basin.

The properties of the Oligocene mudstones in the

Table 1 Some geochemical parameters of Oligocene source rocks in the Qiongdongnan Basin

\begin{tabular}{ccccccc}
\hline Formation & Lithology & TOC, $\%$ & $\mathrm{~S}_{1}+\mathrm{S}_{2}, \mathrm{mg} / \mathrm{g}$ & $\mathrm{I}_{\mathrm{H}}, \mathrm{mg} / \mathrm{g}$ & $T_{\max },{ }^{\circ} \mathrm{C}$ \\
\hline \multirow{2}{*}{ Lingshui Formation } & Dark mudstone & $\frac{0.24-5.25}{0.79(41)}$ & $\frac{0.01-11.10}{0.94(41)}$ & $\frac{19-286}{52(79)}$ & $\frac{362-471}{446(79)}$ \\
& Coal & $\frac{70.9-95.93}{83.42(2)}$ & $\frac{91.66-170.60}{131.13(2)}$ & $231(1)$ & $446(1)$ \\
\hline \multirow{2}{*}{ Yacheng Formation } & Dark mudstone & $\underline{0.20-4.38}$ & $\frac{0.01-6.58}{0.97(41)}$ & $\frac{15-265}{80(59)}$ & $\frac{383-468}{443(59)}$ \\
& Carbonaceous mudstone & $\frac{6.39-9.90}{8.14(4)}$ & $\frac{7.60-24.42}{16.07(4)}$ & $\frac{55-215}{134(5)}$ & $\frac{451-462}{459(5)}$ \\
& Coal & $\frac{32.37-81.3}{53.04(9)}$ & $\frac{13.40-155.40}{94.11(9)}$ & $\frac{28-264}{167(10)}$ & $\frac{427-456}{456(10)}$ \\
\hline
\end{tabular}

Qiongdongnan Basin are complex. Four exploratory wells (YC13-1-2, YC19-1-1, YC21-1-1 in the shallow area and LS4-2-1 in the deep area of central depression zone) from coast area to neritic sea have been chosen in this paper. The results show that the organic matter abundance of the source rocks decreases at first and then begins to increase, and the variation of source rocks in the Yacheng Formation differs substantially from that in the Lingshui Formation (Fig. 3). High quality source rocks of the Yacheng Formation are mainly distributed within the Yacheng Salient, and YC13-1-2 reveals that the source rocks in the Yacheng Formation have a high TOC value, with an average of $3.4 \%$. The organic matter abundance decreases significantly with increasing depth, and YC21-1-1 reveals that the average TOC is only $0.5 \%$. When the depth increases to the relatively deep water area (such as the central depression zone), the organic matter abundance starts to increase, and LS4-2-1 reveals that the average value of TOC is $1.3 \%$. For the source rocks in the Lingshui Formation, the central depression zone is the best zone where high quality source rocks were developed, and LS4-2-1 shows that the average of TOC is $2.4 \%$ in the Lingshui Formation, followed by the Yacheng Salient (Fig. 3).

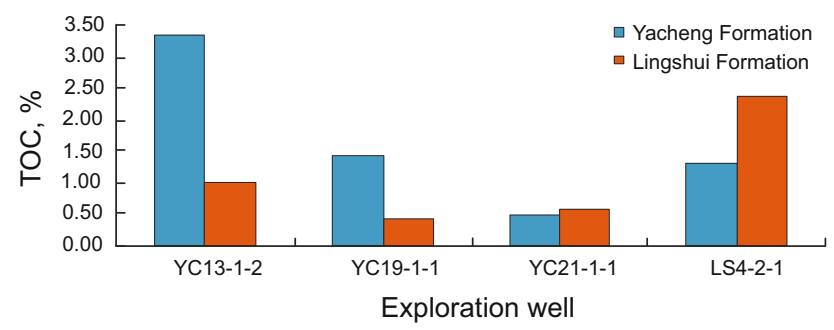

Fig. 3 The distribution characteristics of organic matter abundance of Oligocene source rocks from the coast area to neritic sea in the Qiongdongnan Basin

\section{The main controlling factors of Oligocene source rocks in the Qiongdongnan Basin}

\subsection{Paleoproductivity}

It is suggested by Calvert (1987) that high organic matter abundance of marine sediments is the result of high productivity. It can cause an anoxic bottom water environment. A series of geochemical parameters were utilized to evaluate ocean paleoproductivity. Dymond et al (1992) and Francois et al (1995) independently gave a primary productivity formula by analyzing the amounts of Ba. Murray et al (2000) proposed to analyze qualitatively paleoproductivity by using $\mathrm{Al} / \mathrm{Ti}$, but this index suits an area with low terrigenous material input. Tyrrell (1999) discussed the effect of phosphorus and nitrogen on ocean primary productivity and proposed that some organic bodies can obtain nitrogen from atmosphere when the content of nitrogen decreases, while there is no other way to supply phosphorus when phosphates are exhausted. The changing concentration of phosphates will affect the concentration variation of nitrate, so it is believed that phosphorus determines the primary productivity capacity and $\mathrm{P} / \mathrm{Ti}$ is often used to estimate paleoproductivity (Murray et al, 2000). In addition, $\mathrm{Ni}$ and $\mathrm{Cu}$ are also the indicators of the paleoproductivity (Piper and Perkins, 2004; Naimo et al, 2005).

The input of terrestrial organic matter had a significant effect on Oligocene source rocks in the Qiongdongnan Basin, so $\mathrm{P} / \mathrm{Ti}$ is chosen to reveal the paleoproductivity and we discuss the contribution of lower hydrobionts to source rocks. The values of P/Ti and TOC are not correlated in the Yacheng Formation source rocks and have a negative correlation in the Lingshui Formation (Fig. 4), which indicates that the lower hydrobiont input has no effect on the quality of source rocks. The P/Ti values of source rocks in the Yacheng and Lingshui formations are respectively $0.07-0.19$ and $0.13-0.23$, with the 
average of 0.11 and 0.16 , which is close to the average $\mathrm{P} / \mathrm{Ti}$ value (0.12) in Post Archean Average Shale (PAAS) (Taylor and McLennan, 1985) but is lower than that of average pelagic clay (0.33) and far below that (2-8) associated with regions of high productivity in the equatorial Pacific Ocean (Murray and Leinen, 1993; 1996). The P/Ti value of source rocks in the Lingshui Formation is a little higher than that in the Yacheng Formation while the organic matter abundance is significantly lower (Fig. 4), which indicates that the productivity is rather low and planktons have made little contribution to the Oligocene source rocks. The major source is terrigenous higher plants, while during the period of Lingshui Formation, the contribution of lower hydrobionts to source rocks increases due to expansion of transgression.

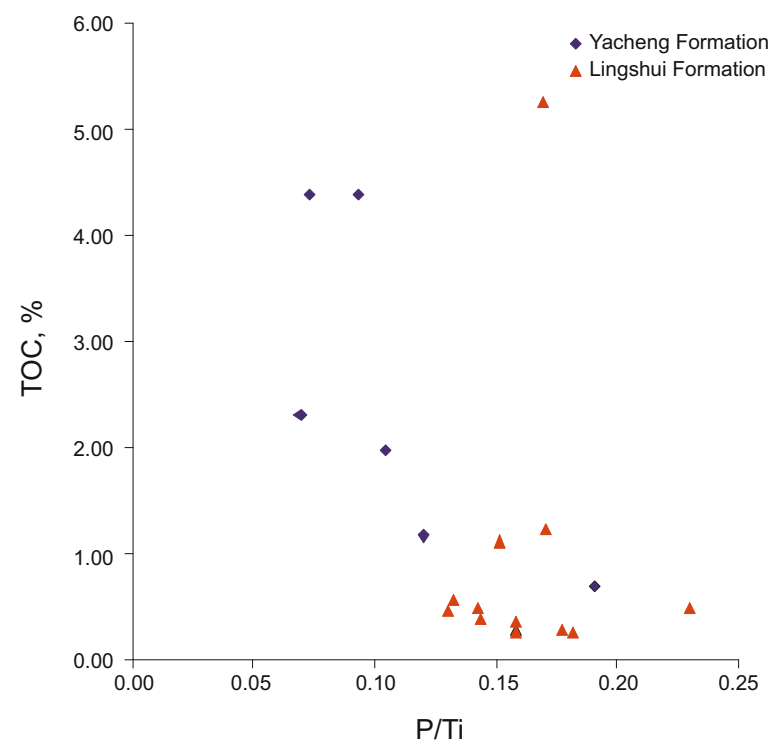

Fig. 4 The cross plot showing the correlation between TOC and P/Ti values of Oligocene source rocks in the Qiongdongnan Basin

\subsection{Terrestrial organic matter input}

Organic macerals are commonly studied to understand hydrocarbon generation characteristics of source rocks, and this is a significant method to identify the heterogeneity and organic compositions of source rocks (Teichmüller, 1986). Kerogen macerals can reflect both the type and the contribution of organic matter. Exinite and sapropelinite are hydrogen-rich macerals which are apt to generate oil while vitrinite has potential to generate gas. In the study area, kerogen is mainly composed of vitrinite and inertinite (more than $60 \%$ ) in the source rocks of the Yacheng Formation while exinite and sapropelinite are less than $40 \%$ (Fig. 5). The types of kerogen are mainly $\mathrm{II}_{2}$ and III, and the organic matter of source rocks is mainly from terrestrial higher plants. In the source rocks of the Lingshui Formation, the kerogen is mainly composed of vitrinite. The contents of vitrinite are $40 \%-80 \%$ in most of samples (some even more than $90 \%$ ), with exinite about $20 \%-50 \%$ and a little sapropelinite. The kerogen is type $\mathrm{II}_{2}$ and III and is mainly contributed by terrestrial higher plants. It is noted that heterogeneity is obvious in kerogen of source rocks due to different sedimentary environments (Fig. 5 ), that is, the source of organic matter is determined by the sedimentary environment.

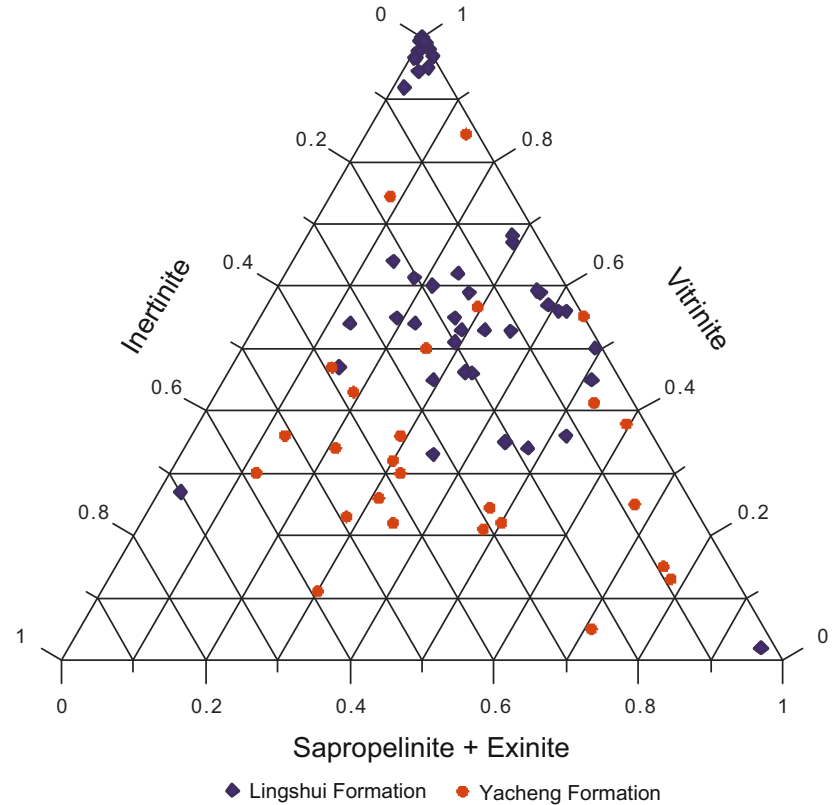

Fig. 5 Triangle chart of relative contents of kerogen compositions of Oligocene source rocks in the Qiongdongnan Basin

As terrestrial higher plants are the main source of organic matter in the study area, the input of terrestrial organic matter is the major controlling factor in the Oligocene sources rocks in the basin. Biomarkers are widely used to assess the origin of organic matter, and some biomarker parameters are used to discuss the relationship between terrestrial organic matter input and organic matter abundance of the source rocks in this paper.

Oleananes were first found in Nigerian petroleum (Whitehead, 1974), and then these compounds have been found in oils and late Mesozoic-Cenozoic source rocks in many other basins in the world, such as the Gippsland Basin (Philp and Gilbert, 1986), Taranaki Basin (Killops et al, 1994; 1995), Yinggehai Basin and Beibuwan Basin of northern South China Sea (Hao et al, 1998; Li et al, 2008). Due to its origin from angiosperms, oleanane is often used to mark the source input and geological age (Moldowan et al, 1994). Although the abundance of oleananes cannot fully reflect the terrestrial plant contribution of the organic matter, the oleanane $/ \mathrm{C}_{30}$ hopane ratio is often used to estimate the contribution from higher plants. In the study area, there is a positive correlation between TOC and the oleanane $/ \mathrm{C}_{30}$ hopane ratio (Fig. 6(a)), which indicates that the input of higher plants controls the organic matter abundance of the Oligocene source rocks in the Qiongdongnan Basin.

Huang and Meinschein (1978) proposed to determine the type of organic matter input by using the relative contents of $\mathrm{C}_{27}-\mathrm{C}_{29}$ regular steranes. The $\mathrm{C}_{27} / \mathrm{C}_{29}$ value of regular steranes is adopted to determine the contribution of terrestrial higher plants to the source rocks in the Qiongdongnan Basin. The values of the ratio in most samples are less than 0.60 (Fig. 6(b)), implying a high content of terrestrial organic matter input. There is a negative correlation between TOC and the $\mathrm{C}_{27} / \mathrm{C}_{29}$ value, so it implies that higher plants input determines the organic matter abundance of the Oligocene source rocks in the basin. 

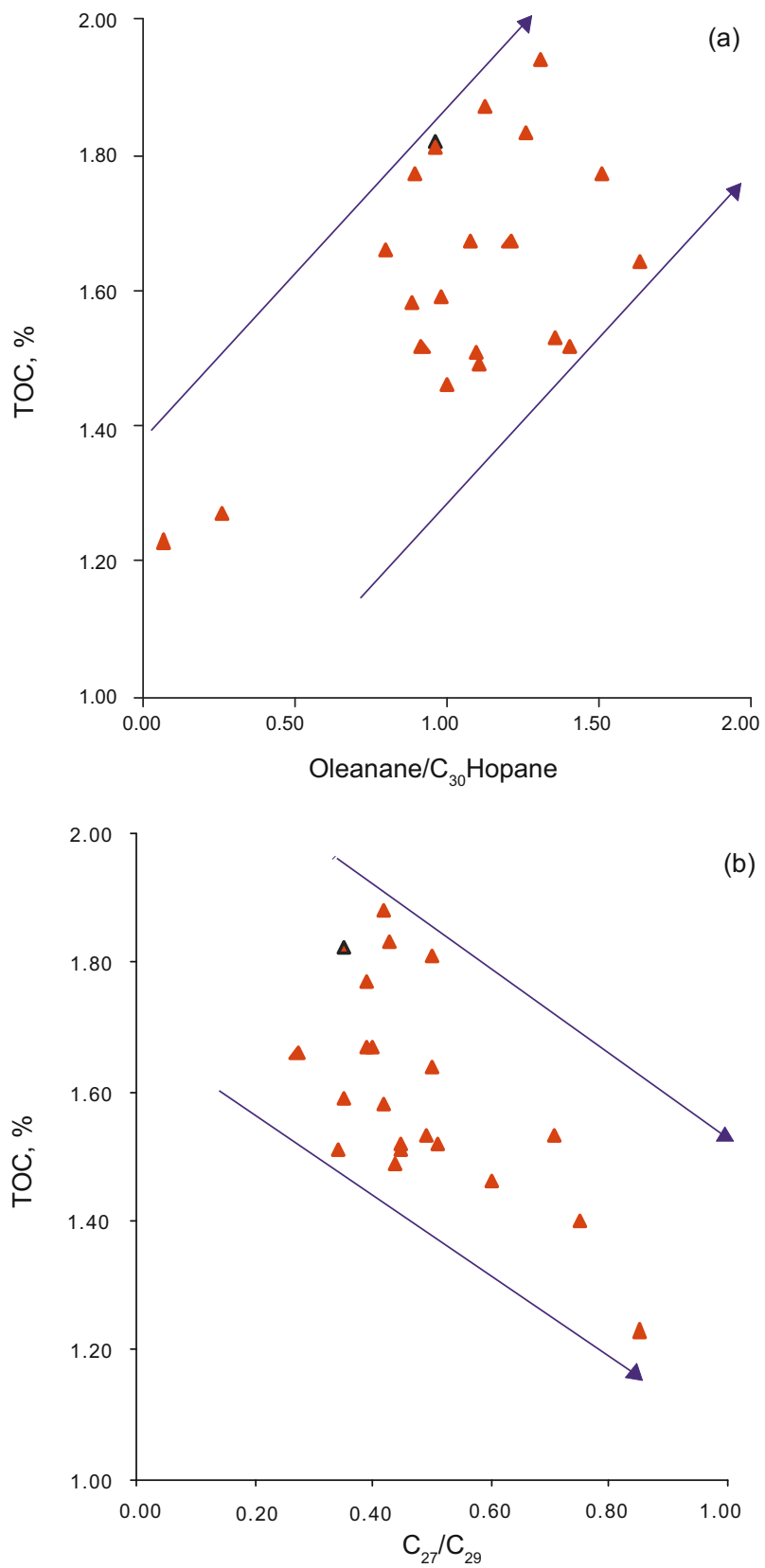

Fig. 6 The cross plot showing the correlation between TOC and some biomarker parameters of Oligocene source rocks in the Qiongdongnan Basin (a) Variation of TOC with oleanane/ $\mathrm{C}_{30}$ hopane value; (b) Variation of TOC with regular sterane $\mathrm{C}_{27} / \mathrm{C}_{29}$ ratio

\subsection{Organic matter preservation}

\subsubsection{Hydrodynamic condition}

Organic matter preservation is influenced by hydrodynamic conditions. The value of $\mathrm{Zr} / \mathrm{Rb}$ is often used to indicate the hydrodynamic conditions. Weak hydrodynamics conditions are favorable for organic matter preservation. High quality marine source rocks develop under the wave base with little disturbance (Qin et al, 2009). The TOC content in Oligocene source rocks shows a negative correlation with the hydrodynamic condition parameter $\mathrm{Zr} / \mathrm{Rb}$ value in the Qiongdongnan Basin, which reveals that the hydrodynamic conditions control the development of the marine source rocks (Fig. 7).

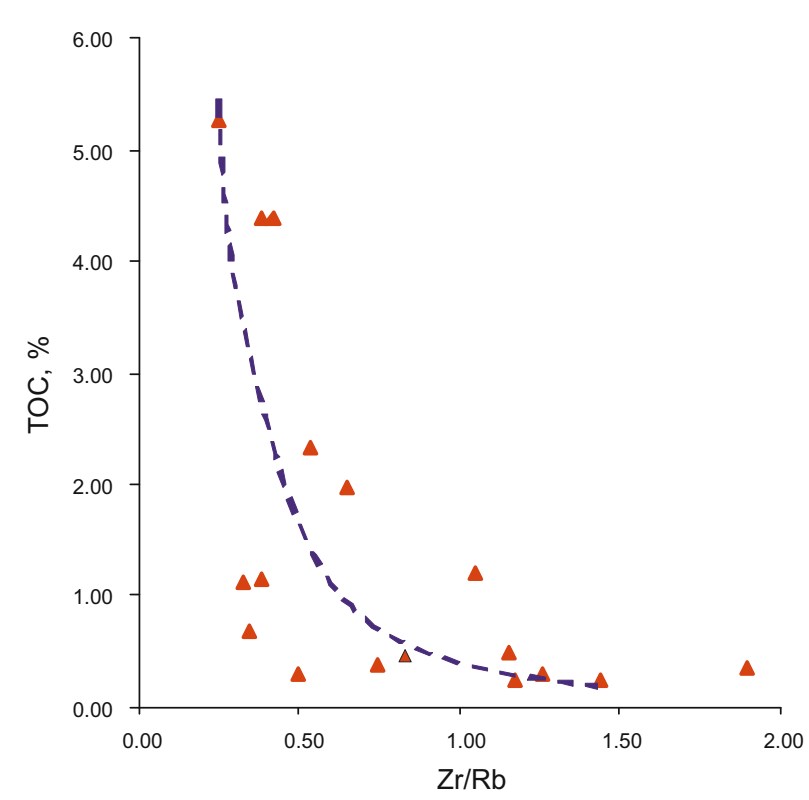

Fig. 7 The cross plot showing the correlation between TOC and $\mathrm{Zr} / \mathrm{Rb}$ values of Oligocene source rocks in the Qiongdongnan Basin

\subsubsection{Redox condition}

The values of U/Th and $\mathrm{Ni} / \mathrm{Co}$ are commonly used to determine redox conditions. Tenger et al (2005) divided the redox conditions into three types according to $\mathrm{U} / \mathrm{Th}$ and $\mathrm{Ni} / \mathrm{Co}$ values: anoxic environment (U/Th>1.25, Ni/Co $>7$ ), suboxic environment (U/Th value from 0.75 to $1.25 ; \mathrm{Ni}$ / Co value from 5 to 7 ), oxic environment $(\mathrm{U} / \mathrm{Th}<0.75, \mathrm{Ni} /$ $\mathrm{Co}<5)$. The U/Th and Ni/Co values of the Oligocene source rocks are respectively below 0.75 and 5 in the Qiongdongnan Basin, and there is no correlation between TOC and these parameters. It indicates that the source rocks were developed in an oxygen-rich environment with little influence of redox conditions (Fig. 8(a), (b)).

\section{Controlling factors of source rocks in different structural zones of the Qiongdongnan Basin}

The input of terrestrial organic matter and hydrodynamic conditions are the major factors controlling the development of the Oligocene source rocks in the Qiongdongnan Basin. We try to indicate the developmental regularity of source rocks by analyzing the two factors in different structural zones of the study area.

\subsection{The comparison of terrestrial higher plants input of source rocks in different structural zones}

Exploratory well LS4-2-1 intersects the Yacheng Formation in the central depression zone of the Qiongdongnan Basin, and there is no relevant data on organic macerals. In this paper, we choose wells YC13-1-3, YC19-1-1 and YC211-4 from north (coast area) to south (neritic sea) to discuss the input of higher plants by analyzing the macerals of source rocks (Fig. 9). From coast area to neritic sea, the content of sapropelinite has an increasing trend while the content of 

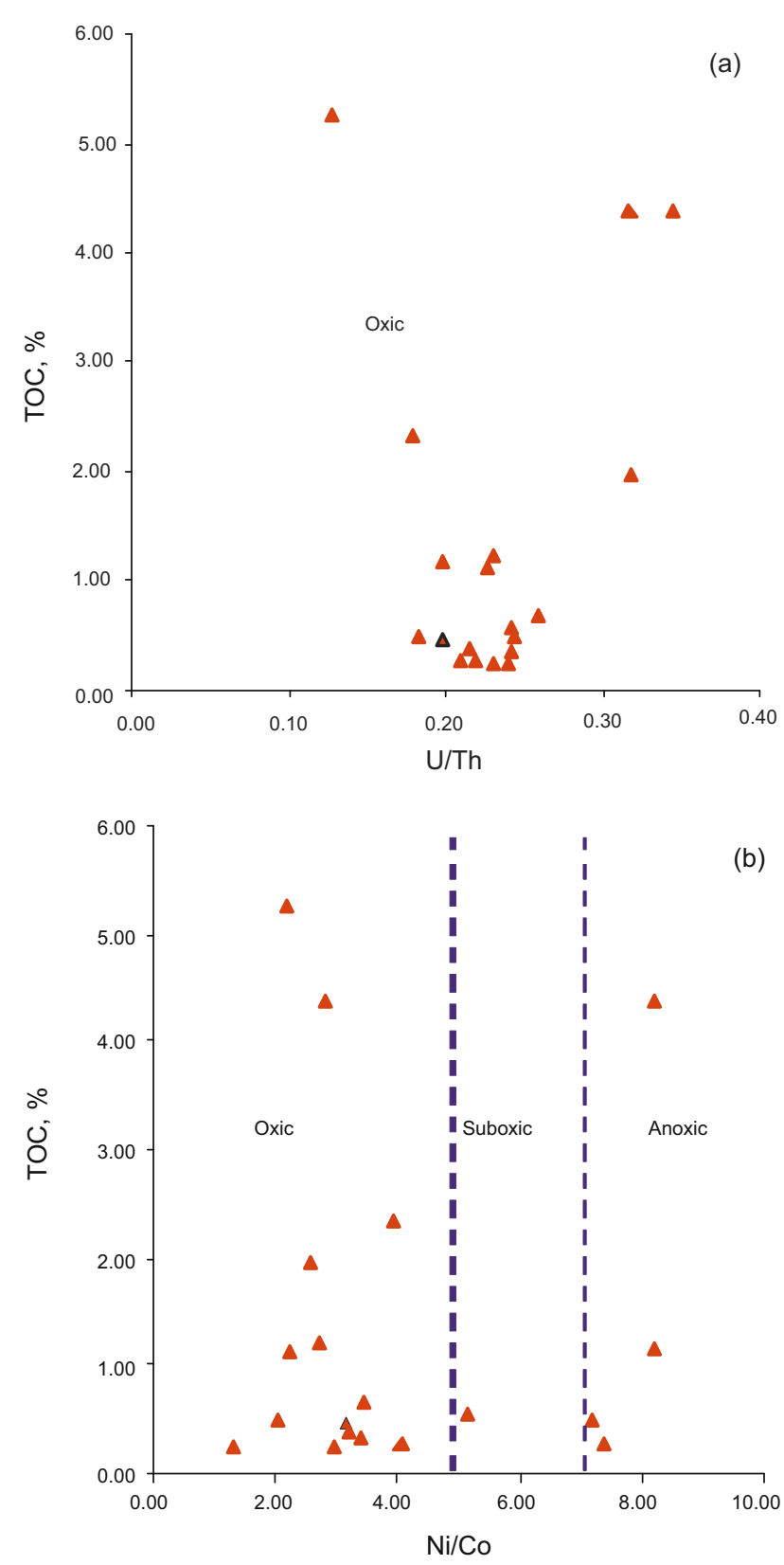

Fig. 8 The cross plot showing the correlation between TOC and some redox parameters of Oligocene source rocks in the Qiongdongnan Basin (a) Variation of TOC with U/Th; (b) Variation of TOC with Ni/Co

vitrinite and inertinite decreases. It indicates that the input of higher plants decreases. In the central depression zone, the amount of terrestrial organic matter is high, and well LS4-2-1 with high organic matter abundance in the Yacheng Formation is good evidence (Fig. 3). It is largely because Hainan Island and the southern uplift zone provided relatively abundant organic matter in the sedimentary period of the Yacheng Formation (Yao et al, 2008).

In the sedimentary period of the Lingshui Formation, the content of sapropelinite in the source rocks decreases while the content of vitrinite and inertinite increases gradually from the northern depression zone to the central depression zone (Fig. 10). It implies that terrestrial higher plants instead of plankton control the development of source rocks. The

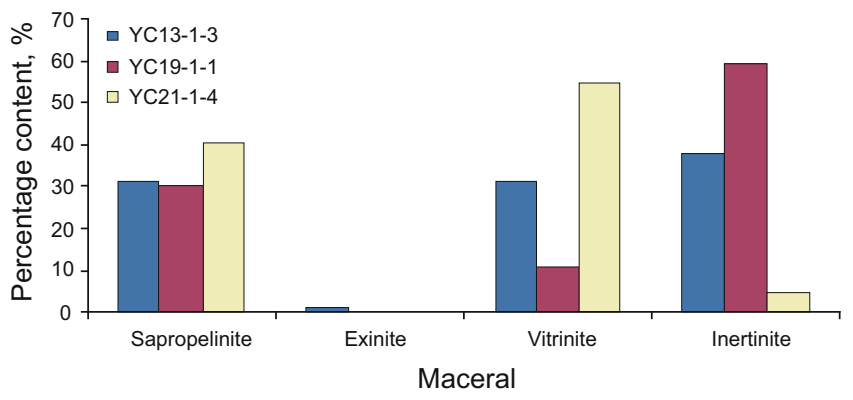

Fig. 9 The distribution characteristics of macerals in source rocks of the Oligocene Yacheng Formation from the coast area to neritic sea of the Qiongdongnan Basin

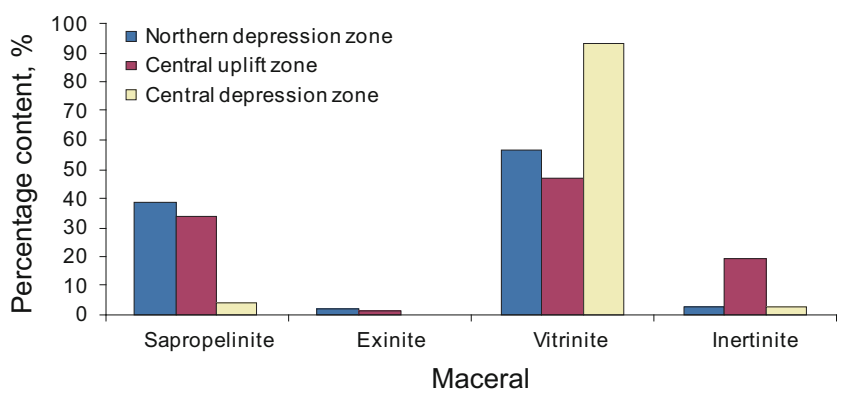

Fig. 10 The distribution characteristics of macerals in source rocks of the Oligocene Lingshui Formation in different structural zones of the Qiongdongnan Basin

high organic matter abundance of source rocks developed in the central depression zone (revealed by well LS4-2-1 as shown in Fig. 3) is attributed to the terrestrial organic matter provided by the Hainan Island and southern uplift zone of the basin.

\subsection{Hydrodynamic conditions in different structural zones}

Hydrodynamic conditions differ in different structural zones of the Qiongdongnan Basin. During the sedimentary period of the Yacheng Formation, the source rocks in the northern depression zone and central uplift zone were developed in tidal flat and lagoon environments with low $\mathrm{Zr}$ / $\mathrm{Rb}$ values showing weak hydrodynamic conditions (Fig. 11). It indicates favorable organic matter preservation. The source rocks in the central depression zone were mainly developed in a littoral-neritic sea environment with relatively strong hydrodynamic conditions, implying unfavorable preservation condition compared with the northern depression zone. During the sedimentary period of the Lingshui Formation, the source rocks in the northern depression zone were developed in a littoral-neritic environment with relatively strong hydrodynamic conditions, indicating poor organic matter preservation. The source rocks in the central uplift zone were developed in a coastal plain environment with the calmest hydrodynamic conditions, showing the most favorable organic matter preservation. The average value of $\mathrm{Zr} / \mathrm{Rb}$ in the Yacheng Formation is significantly lower than that in the Lingshui Formation. It shows that the hydrodynamic conditions of the Yacheng Formation are relatively weak, and 


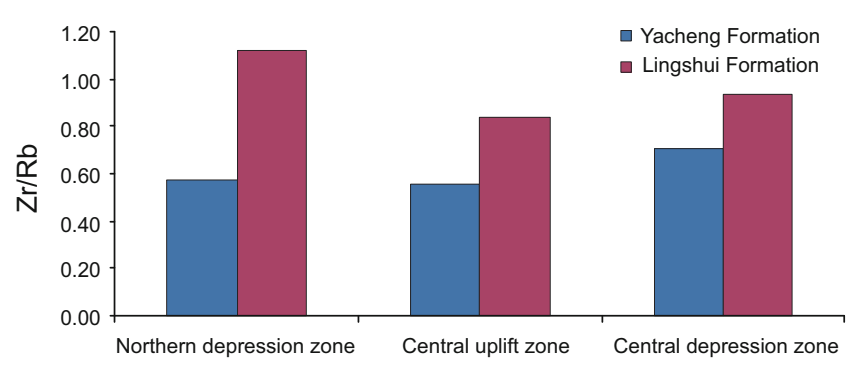

Fig. 11 The distribution of $\mathrm{Zr} / \mathrm{Rb}$ in Oligocene source rocks in different structural zones of the Qiongdongnan Basin

the organic matter preservation is better. It explains why the organic matter abundance of the source rocks in the Yacheng Formation is better than that in the Lingshui Formation.

\section{Developmental model of Oligocene source rocks in the Qiongdongnan Basin}

\subsection{Developmental model of source rocks of the Yacheng Formation}

During the sedimentary period of the Yacheng Formation, source rocks in the northern depression zone were mainly developed in delta, tidal flat and lagoon environments where there was abundant terrestrial organic matter. A delta environment, with strong hydrodynamic conditions, is not favorable for the development of source rocks. Source rocks in the central uplift zone were developed in a tidal flat environment which was beneficial for coal formation, and the Yacheng Salient was the most favorable place. Because the transgression was weak, source rocks in the central depression were mainly developed in a littoral-neritic environment with relatively strong hydrodynamic and oxidative conditions, resulting in poor organic matter preservation. The supply of sediments from the uplift of Hainan Island reduced but organic matter was obtained from the southern uplift zone, so source rocks with good hydrocarbon potential were also formed in the central depression zone (Fig. 12).

\subsection{Developmental model of source rocks of the Lingshui Formation}

During the sedimentary period of the Lingshui Formation, the scope of marine facies continued to expand. The basin had a littoral-neritic environment and partially fan delta. Source rocks in the northern depression zone were developed in littoral-neritic environment with strong hydrodynamic conditions and an oxidative environment, resulting in poor organic matter preservation. This is not favorable for the development of source rocks. Source rocks in the central uplift zone were developed in a coastal plain environment with good conditions for organic matter accumulation, especially in the Yacheng Salient area, where source rocks have a rather high hydrocarbon potential with abundant terrestrial organic matter input. Source rocks in the central depression zone were developed in neritic facies, where the input of terrestrial organic matter is abundant owing to multiple supplies of sediments. The semi-enclosed system was beneficial for the development of marine source rocks (Fig. 13).

\section{Conclusions}

1) Source rocks in the Oligeocene Yacheng and Lingshui formations are the major source rocks in the Qiongdongnan Basin, but heterogeneity of the source rocks is strong in different sedimentary environments. Source rocks are mainly controlled by the input of terrestrial organic matter and hydrodynamic conditions.

2) During the sedimentary period of the Yacheng Formation, source rocks in the central uplift zone were developed in tidal flat environment with abundant terrestrial organic matter input and weak hydrodynamic conditions. The central uplift zone is the most favorable zone for the development of source rocks, especially the area of Yacheng Salient. The central depression zone is also suitable for the development of source rocks owing to the terrestrial organic matter provided by the Hainan Island and southern uplift zone.

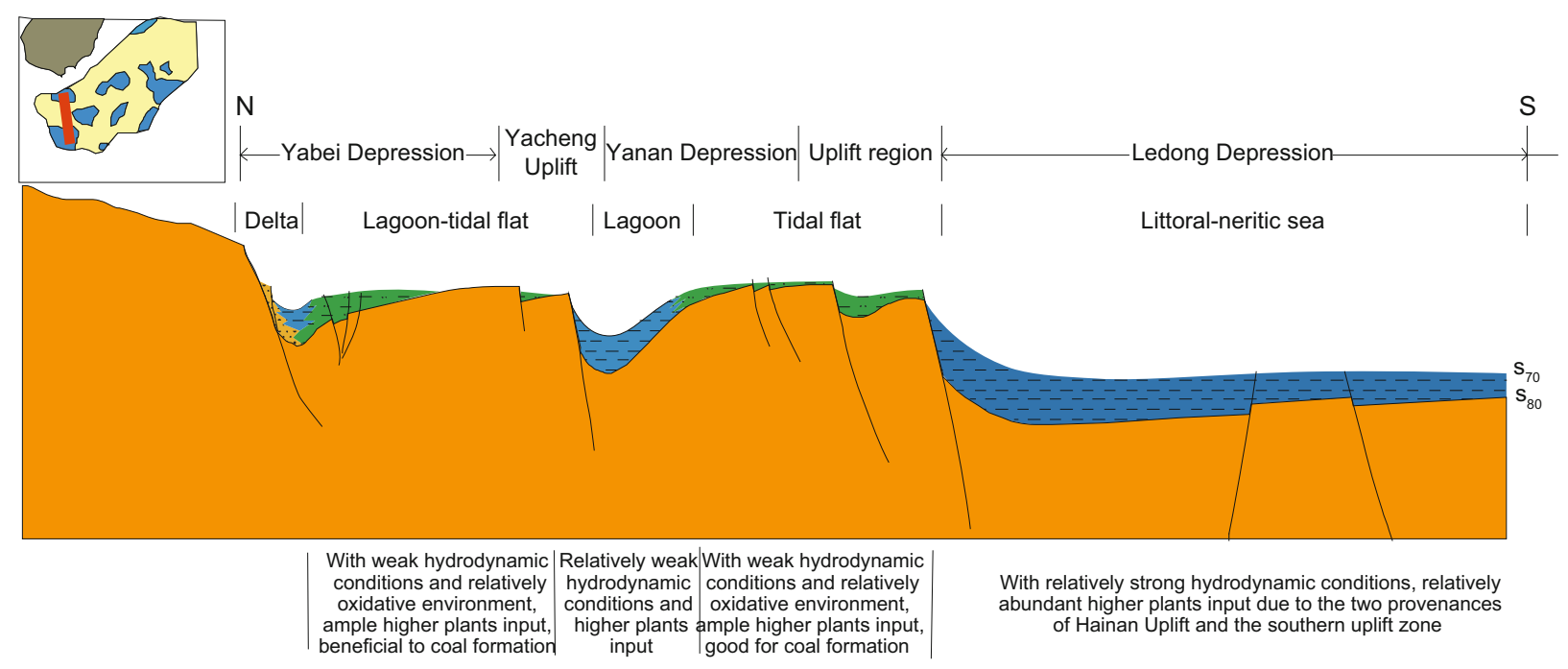

Fig. 12 Developmental model of source rocks of the Yacheng Formation in the Qiongdongnan Basin 


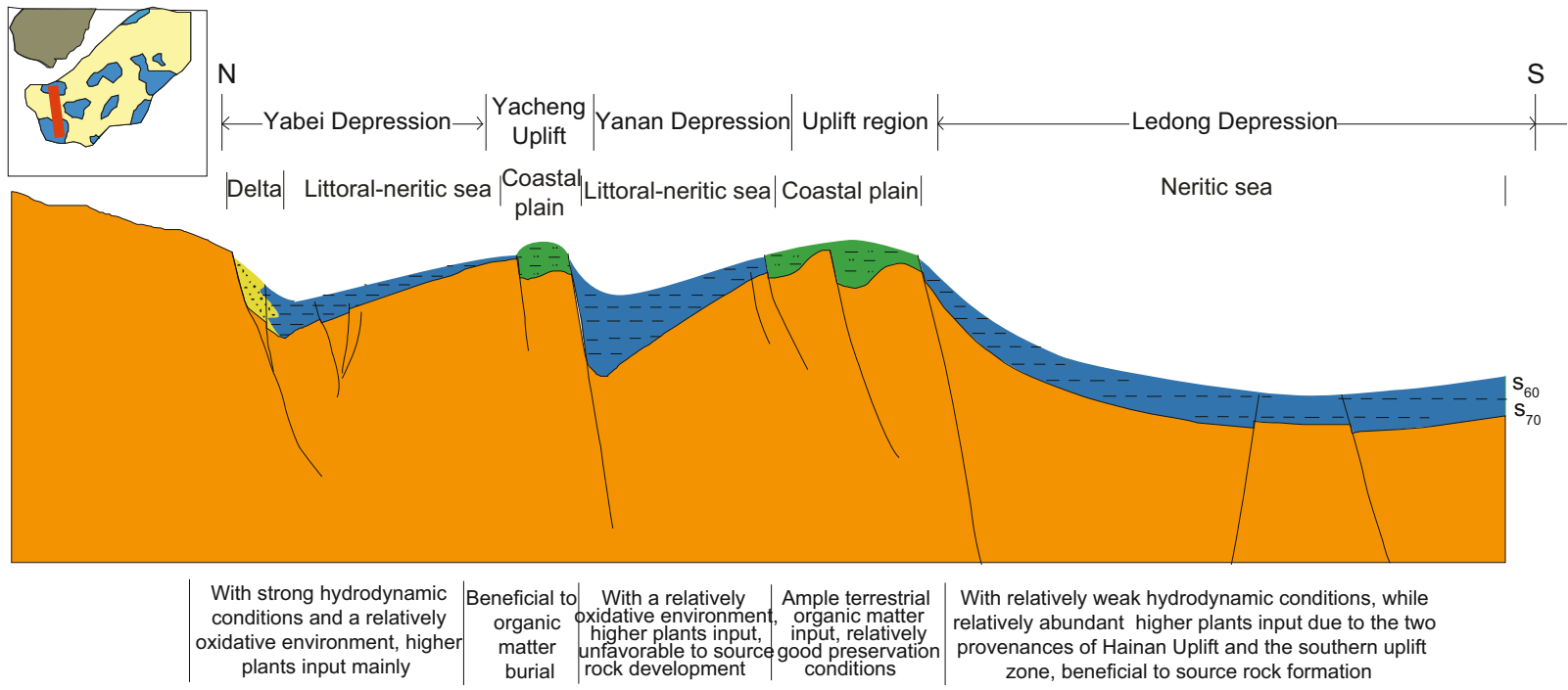

Fig. 13 Developmental model of source rocks of the Lingshui Formation in the Qiongdongnan Basin

3) During the sedimentary period of the Lingshui Formation, the input of terrestrial organic matter was sufficient in the central depression zone, and the semienclosed system was favorable for organic matter accumulation. High quality marine source rocks formed in the central depression zone. Source rocks were also developed in the Yacheng Salient of the central uplift zone due to the abundant terrestrial organic matter and weak hydrodynamic conditions.

\section{Acknowledgements}

This project was financially supported by the Major State Basic Research Development Program (973 Program) (Grant No. 2009CB219402). The authors would like to thank CNOOC for providing the source rock samples.

\section{References}

Calvert S E. Oceanographic controls on the accumulation of organic matter in marine sediments. In: Brooks J D and Fleet A J, eds. Marine Petroleum Source Rock. Geological Society of London Special Publication. 1987. 137-151

Calvert S E and Pedersen T F. Organic carbon accumulation and preservation in marine sediments: How important is anoxia? In: Whelan J K and Farrington J W, eds. Productivity, Accumulation and Preservation of Organic Matter in Recent and Ancient Sediments. New York: Columbia University Press. 1992. 231-263

Chen J F, Zhang S C, Bao Z D, et al. Main sedimentary environments and influencing factors for development of marine organic-rich source rocks. Marine Origin Petroleum Geology. 2006. 11(3): 49-54 (in Chinese)

Chen W H, He J X and Xia B. Review and proposal upon offshore gas exploration in Yingqiong Basin. Natural Gas Geoscience. 2005. 14(4): 412-415 (in Chinese)

Deng Y H. River-gulf system - the major location of marine source rock formation. Petroleum Science. 2012. 9(3): 281-289

Dong W L and Huang B J. Identification marks and source discrimination of the coal type gas in Yinggehai and Qiongdongnan Basins of South China Sea. Natural Gas Industry. 2000. 20(1): 2327 (in Chinese)

Dymond J, Suess E and Lyle M. Barium in deep-sea sediment: A geochemical proxy for paleoproductivity. Paleoceanography. 1992. 7: $163-181$

Francois R, Honjo S, Manganini S J, et al. Biogenic barium fluxes to the deep sea: Implications for paleoproductivity reconstruction. Global Biogeochemical Cycles. 1995. 9(2): 289-303

Gong C L, Wang Y M, Zhu W L, et al. The central submarine canyon in the Qiongdongnan Basin, northwestern South China Sea: Architecture, sequence stratigraphy, and depositional processes. Marine and Petroleum Geology. 2011. 28(9): 1690-1702

Hao F, Li S T, Sun Y C, et al. Geology, compositional heterogeneities, and geochemical origin of the Yacheng gas field, Qiongdongnan Basin, South China Sea. AAPG Bulletin. 1998. 82(7): 1372-1384

$\mathrm{Hu} \mathrm{Z}$ L. Study on petroleum generation kinetics of source rocks and gas pool formation in the Yanan Depression of the Qiongdongnan Basin. Ph.D. Thesis. Chinese Academy of Science, Guangzhou Institute of Geochemistry. 2005 (in Chinese)

Huang B J, Li L and Huang H T. Origin and accumulation mechanism of shallow gas in the North Baodao Slope, Qiongdongnan Basin. Petroleum Exploration and Development. 2012. 39(5): 567-573

Huang B J, Xiao X M and Dong W L. Characteristics of hydrocarbon source rocks and generation \& evolution model of natural gas in Yinggehai Basin. Natural Gas Industry. 2002. (1): 26-32 (in Chinese)

Huang W Y and Meinschein W G. Sterols in sediments from Baffin Bay, Texas. Geochimica et Cosmochimica Acta. 1978. 42(9): 1391-1396

Killops S D, Raine J I, Woolhouse A D, et al. Chemostratigraphic evidence of higher-plant evolution in the Taranaki Basin, New Zealand. Organic Geochemistry. 1995. 23(5): 429-445

Killops S D, Woolhouse A D, Weston R J, et al. A geochemical appraisal of oil generation in the Taranaki Basin, New Zealand. AAPG Bulletin. 1994. 78: 1560-1585

Li M J, Wang T G, Liu J, et al. The occurrence of oleananes in the Beibuwan Basin and its application to the study of maturity and oilsource rock correlation. Acta Geologica Sinica. 2008. 82(3): 585-595

Li W H, Zhang Z H, Li Y C, et al. Geochemical characteristics and hydrocarbon generation of Paleogene Oligocene source rocks in Qiongdongnan Basin. Natural Gas Geoscience. 2011. 22(4): 700-708 (in Chinese)

Li W H, Zhang Z H, Li Y C, et al. New perspective of Miocene marine hydrocarbon source rocks in deep-water area in Qiongdongnan Basin of northern South China Sea. Acta Oceanologica Sinica. 2012. 31(5): $1-8$

Moldowan J M, Dahl J, Huizinga B J, et al. The molecular fossil record 
of oleanane and its relation to angiosperms. Science. 1994. 265: 768-771

Murray R W, Knowlton C, Leinen M, et al. Export production and carbonate dissolution in the central equatorial Pacific Ocean over the past 1Myr. Paleoceanography. 2000. 15(6): 570-592

Murray R W and Leinen M. Chemical transport to the seafloor of the equatorial Pacific Ocean across a latitudinal transect at $135^{\circ} \mathrm{W}$ : Tracking sedimentary major, trace, and rare earth element fluxes at the Equator and the intertropical convergence zone. Geochimica et Cosmochimica Acta. 1993. 57(17): 4141-4163

Murray R W and Leinen M. Scavenged excess Al and its relationship to bulk Ti in biogenic sediment from the central equatorial Pacific Ocean. Geochimica et Cosmochimica Acta. 1996. 60(20): 38693878

Naimo D, Adamo P, Imperato M, et al. Mineralogy and geochemistry of a marine sequence, Gulf of Salerno, Italy. Quaternary International. 2005. 140-141: 53-63

Philp R P and Gilbert T D. Biomarker distributions in Australian oils predominantly derived from terrigenous source material. Organic Geochemistry. 1986. 10(1-3): 73-84

Piper D Z and Perkins R B. A modern vs. Permian black shale-the hydrography, primary productivity, and water-column chemistry of deposition. Chemical Geology. 2004. 206(3-4): 177-197

Qin J Z, Tenger and Fu X D. Study of formation condition on marine excellent source rocks and its evaluation. Petroleum Geology \& Experiment. 2009. 31(4): 366-372, 378 (in Chinese)

Taylor S R and McLennan S M. The Continental Crust: Its Composition and Evolution. Blackwell, Malden, Mass. 1985

Teichmüller M. Organic petrology of source rocks, history and state of the art. Organic Geochemistry. 1986. 10(1/3): 581-599

Tenger, Liu W H, Xu Y C, et al. Correlative study on parameters of inorganic geochemistry and hydrocarbon source rocks formative environment. Advances in Earth Science. 2005. 20(2): 193-200 (in
Chinese)

Tyrrell T. The relative influences of nitrogen and phosphorus on oceanic primary production. Nature. 1999. 400: 525-531

Tyson R V. The genesis and palynofacies characteristics of marine petroleum source rocks. In: Brooks J D and Fleet A J, eds. Marine Petroleum Source Rocks. Geological Society of London Special Publication. 1987. 26: 47-67

Tyson R V and Pearson T H. Modern and ancient continental shelf anoxia: An overview. Geological Society of London Special Publication. 1991. 58: 1-24

Whitehead E V. The structure of petroleum pentacyclanes. In: Tissot B and Bienner F (eds.). Advances in Organic Geochemistry. Paris: Editions Technip. 1974. 225-243

Xiao X M, Xiong M, Tian H, et al. Determination of the source area of the Ya13-1 gas pool in the Qiongdongnan Basin, South China Sea. Organic Geochemistry. 2006. 37(9): 990-1002

Yao G S, Yuan S Q, Wu S G, et al. Double provenance depositional model and exploration prospect in deepwater area of Qiongdongnan Basin. Petroleum Exploration and Development. 2008. 35(6): 685691 (in Chinese)

Zhang S C, Zhang B M, Bian L Z, et al. Development constraints of marine source rocks in China. Earth Science Frontiers. 2005. 12(3): 39-48 (in Chinese)

Zhou D, Sun Z and Chen H Z. Tectonic features of world's major deep-water oil/gas fields and their enlightenment to deep-water exploration in northern South China Sea. Advances in Earth Science. 2007. 22(6): 561-572 (in Chinese)

Zhu W L, Huang B J, Mi L J, et al. Geochemistry, origin, and deepwater exploration potential of natural gases in the Pearl River Mouth and Qiongdongnan basins, South China Sea. AAPG Bulletin. 2009. 93(6): 741-761

(Edited by Hao Jie) 